\title{
Implementation of the ARCS Learning Model and Building Component Teaching Aids to Improve Learning Outcomes of State Vocational High School Students
}

\author{
Roemintoyo $^{1, *}$, Conietta Vyonella Zeyn ${ }^{2}$, Aryanti Nurhidayanti ${ }^{3}$, Mochamad Kamil Budiarto ${ }^{4}$ \\ ${ }^{1}$ Faculty of Teacher Training and Education, Sebelas Maret University, Indonesia \\ ${ }^{2}$ Faculties of Teacher Training and Education, Sebelas Maret University, Indonesia \\ ${ }^{3}$ Faculty of Teacher Training and Education, Sebelas Maret University, Indonesia \\ ${ }^{4}$ STIPER Institute of Agriculture, Yogyakarta \\ *Corresponding author: roemintoyo@staff.uns.ac.id
}

\begin{abstract}
This research aims to determine student learning outcomes in the subject of budget estimate plan by implementing building component teaching aids and ARCS (attention, relevance, confidence, satisfaction) learning models. This research applied the classroom action research (CAR) model. The research was conducted in three cycles. The research subjects involved state vocational high school students in Sukoharjo. The research began with identifying the existing problems in the classroom by carrying out a pre-cycle. Cycle I started with a planning cycle in the form of the learning preparation steps by applying ARCS learning models and building component teaching aids. Meanwhile, action, observation, and reflection were done in Cycle II and Cycle III. Based on this study's results, the ARCS learning model and building component teaching aids could improve student learning outcomes.
\end{abstract}

Keywords: media building components, ARCS, learning outcomes.

\section{Introduction}

Schools play an essential role in developing students competencies. In their competence development, students must be able to solve problems in small contexts at school, which will later be applied in the surrounding environment [1]. In this case, in the vocational high school curriculum for building engineering majors, various subjects cover adaptive, normative, and productive learning [2], [3]. One of the productive subjects that must be studied in this major is the budget estimate plan (RAB), which encompasses how to calculate expenditure budgets and estimates in constructing a building [4],[2].

Formerly, the budget estimate plan subject in the KTSP curriculum was given to class XII in even semesters on the grounds that students have first understood the various building components studied in classes $\mathrm{X}$ and $\mathrm{XI}$. However, the change of curriculum into the 2013 curriculum has made budget estimate plan subject given to class $\mathrm{X}$, where this material delivery is not too deep, both in budget estimate plan subject and other subjects related

to building engineering [5],[6],[7]. It was revealed that students could work on various budget estimate plan questions but did not understand what they were calculating. From the discussion results, coupled with direct observations by the researchers before carrying out the research, it was uncovered that there were obstacles in the learning process of budget estimate plan subject, in which many students still did not comprehend the material taught by the teacher. It was because teachers who taught budget estimate plan subject still used the lecture teaching method before the class. Friskawati \& Sobarna [8] stated that the learning process must involve the student's psychological aspects, both physically and spiritually, to accelerate behavior change quickly, precisely, efficiently, and correctly, either related to cognitive, affective, or 
psychomotor aspects. The learning process here is defined as a person's internal activities, consisting of various events strung into stages, forming the learning process [9],[10]. In addition, events around the subject can either support or hinder the learning process.

We all know that learning is a process of interaction between students and their environment, this will then cause changes in themselves, both cognitively, affectively and psychomotor. However, learning activities are influenced by a condition, both internal and external. A very strong internal influence in achieving learning objectives is interest. With a strong interest in learning, it will be able to achieve learning goals easily. In this case, interest is included in the motivational element in the ARCS Motivation Model.

On the other hand, the ARCS learning model was developed based on the expectancy-value theory, containing two components: the value of the goal to be achieved and the expectancy to successfully achieve that goal [11]. Of the two components, Keller developed them into four components [12]. The four learning model components consist of attention, relevance, confidence, and satisfaction (ARCS) [12],[13]. This ARCS learning model prioritizes student attention, adapts learning materials to student learning experiences, creates selfconfidence, and generates a sense of satisfaction in students [14].

More specifically, a budget estimate plan for a building or project is a calculation of the costs required for materials, wages, and other costs related to the implementation of the building or project. Besides, the budget is explained as the price of building materials, calculated carefully, and meets the requirements. The budget estimate plan is then gauged based on easy-todetermine plan drawings and specifications, wages for labor, and work tools [2]. In the construction process, estimates include many things, embracing various purposes and interests for diverse organizations' managements.

Furthermore, teaching aids are vital for achieving maximum learning outcomes; teaching aids can be in the form of learning media or other supporting tools [15],[16]. In a limited sense, teaching aids are several objects or equipment that function to assist the learning process [15]. These teaching aids can be in the form of real or imitation objects [17]. In this case, a miniature model results from simplifying a reality but does not show activity; it can help students about the details of an object to be the discussion subject in three dimensions [18], [19].

Based on the background of the problem above, look at the effectiveness of using the ARCS learning model. So this study aims to determine the increase in student learning outcomes in class $\mathrm{X}$ architectural drawings at Vocational High School in Sukoharjo, especially in the subject of budget planning, which in the learning process applies the ARCS learning model and building component learning devices.

\section{Methodology}

This classroom action research was carried out at Vocational....High ....S.chool ....in ....S. Sukoharjo, ,........ith.... research subjects that amounted to 35 students. The data were obtained after carrying out the test and were further analyzed. This data analysis aimed to answer the questions raised previously in this study.

This research was carried out before the covid-19 pandemic, this means that the learning process is still carried out with face-to-face meetings, between teachers and students in the classroom. During the learning activities, the researchers paid attention to two aspects: student motivation and activities during the learning process and student learning outcomes. The researchers also observed students' enthusiasm when participating in learning; for example, students provided feedback and were interested in the teaching aids provided and the students' condition in completing tests at the end of learning, whether asking friends or working individually.

Data collection tools were in the form of observation sheets and final test results. The data analysis and processing were then carried out after the learning process was complete. In this case, two types of student data were required: activities during the learning process and data about student learning outcomes. The data were then processed by the formula according to Dimyati \& Mudjiono [20]:

$$
\mathrm{P} \%=\mathrm{F} / \mathrm{N} \times 100 \%
$$

\section{Information:}

$$
\begin{aligned}
& \mathrm{P} \%=\text { Average percentage of student activity } \\
& \mathrm{F}=\text { Number of active students } \\
& \mathrm{N}=\text { Total number of students }
\end{aligned}
$$

Table 1. Criteria for student learning activity

\begin{tabular}{|c|c|}
\hline Category & Percentage Range \\
\hline Very little & $1 \%-25 \%$ \\
\hline Little & $26 \%-50 \%$ \\
\hline Many & $51 \%-75 \%$ \\
\hline Numerous & $76 \%-100 \%$ \\
\hline
\end{tabular}

Student learning outcomes could be seen based on the test results obtained by students. It was to know the extent to which students have understood the material given, using the formula according to Sudjana [21]:

$$
\mathrm{X}=\sum \mathrm{Xi} / \mathrm{N}
$$

\section{Information:}

$\mathrm{X}=$ Average

$\mathrm{Xi}=$ The score of each student taking the test

$\mathrm{N}=$ The number of students taking the test

To determine the achievement of learning objectives, it is necessary to formulate indicators of the success of prepared actions realistically and measurably. The cognitive aspect is the assessment of learning outcomes on the achievement of scores obtained by students in the 
learning process. As explained above, the achievement of minimum completeness criteria was 77 , with a percentage of students as much as $75 \%$.

Table 2. Cognitive aspect

\begin{tabular}{ccc}
\hline Measured Aspect & $\begin{array}{c}\text { Targeted Score } \\
\text { Percentage }\end{array}$ & How to Measure \\
\hline $\begin{array}{c}\text { The score obtained } \\
\text { during the written } \\
\text { test/exam }\end{array}$ & 77 as much as $75 \%$ & $\begin{array}{c}\text { Measured from the } \\
\text { written test results } \\
\text { after the learning } \\
\text { took place }\end{array}$ \\
\hline
\end{tabular}

The psychomotor aspect relates to the students' abilities to show expertise and skills in class. For the psychomotor aspect assessment, three activity categories were taken, including writing, drawing, and motoric activities, since they represented the psychomotor aspect.

Table 3. Psychomotor aspect

\begin{tabular}{ccc}
\hline Measured Aspect & $\begin{array}{c}\text { Targeted Score } \\
\text { Percentage }\end{array}$ & How to Measure \\
\hline $\begin{array}{c}\text { Learning activities } \\
\text { include writing, drawing, } \\
\text { and motoric activities. }\end{array}$ & $75 \%$ & $\begin{array}{c}\text { Observed during the } \\
\text { learning process by } \\
\text { counting the number } \\
\text { of students who got } \\
\text { a score of } \geq 2.66 \text { (B- }\end{array}$ \\
\hline
\end{tabular}

The affective aspect associates with the students' abilities to behave and whether they are active in participating in classroom activities. In this study, for the affective aspect assessment, five activity categories were considered: visual, oral, mental, listening, and emotional activities, as they demonstrated in assessing the affective domain.

Table 4. Affective aspect

\begin{tabular}{lcc}
\hline Measured Aspect & $\begin{array}{c}\text { Targeted Score } \\
\text { Percentage }\end{array}$ & How to Measure \\
\hline $\begin{array}{c}\text { Learning activities cover } \\
\text { visual, oral, mental, } \\
\text { listening, and emotional } \\
\text { activities. }\end{array}$ & $75 \%$ & $\begin{array}{c}\text { Observed during the } \\
\text { learning process by } \\
\text { counting the number } \\
\text { of students who got } \\
\text { a score of } 2.66(\mathrm{~B}-)\end{array}$ \\
\hline
\end{tabular}

\section{Results}

In this research, the first stage is planning, all forms of preparation and action plan to be carried out in learning to improve student learning activities and outcomes. This stage included preparing lesson plans (RPP), designing learning models, compiling learning modules, making learning aids/media, preparing student observation sheets, and preparing for learning outcomes tests.

Activities that occur during implementation are adjustments to learning planning so that the learning process will consist of activities delivering material orally by teachers to students, as well as practical learning in accordance with the curriculum and learning objectives on each subject.
The next stage is action. The action chosen to overcome emerging problems was to increase budget estimate plan subject's activities and learning outcomes by applying the ARCS learning model. The steps taken comprised the introduction, core, and closing activities. The following are the respective results obtained during the research implementation.

Table 5. Introduction activities

\begin{tabular}{|c|c|}
\hline Teacher Activities & Student Activities \\
\hline $\begin{array}{c}\text { The teacher opens the lesson and motivates } \\
\text { students to be enthusiastic in participating in } \\
\text { learning. }\end{array}$ & $\begin{array}{c}\text { Students pay } \\
\text { attention and listen. }\end{array}$ \\
\hline $\begin{array}{c}\text { The teacher provokes students by asking } \\
\text { questions related to the material to be studied. }\end{array}$ & $\begin{array}{c}\text { Students pay } \\
\text { attention and listen. }\end{array}$ \\
\hline $\begin{array}{c}\text { The teacher describes the objectives and } \\
\text { benefits of learning to be presented (R). }\end{array}$ & $\begin{array}{c}\text { Students pay } \\
\text { attention and listen. }\end{array}$ \\
\hline $\begin{array}{c}\text { The teacher conveys the indicators to be } \\
\text { achieved. }\end{array}$ & $\begin{array}{c}\text { Students pay } \\
\text { attention and listen. }\end{array}$ \\
\hline
\end{tabular}

Table 6. Core activities

\begin{tabular}{|c|c|}
\hline Teacher Activities & Student Activities \\
\hline $\begin{array}{c}\text { The teacher gives the material for } 15 \\
\text { minutes and relates the learning to daily } \\
\text { activities (A). }\end{array}$ & $\begin{array}{c}\text { Students listen, pay } \\
\text { attention, and take } \\
\text { notes. }\end{array}$ \\
\hline $\begin{array}{c}\text { The teacher brings out the teaching aids } \\
\text { before the class (A \& R). }\end{array}$ & $\begin{array}{c}\text { Students pay attention } \\
\text { to the teaching aids. }\end{array}$ \\
\hline $\begin{array}{c}\text { Students are appointed one by one to come } \\
\text { to the front of the class explaining the } \\
\text { building components (R \& C). }\end{array}$ & $\begin{array}{c}\text { Students come to the } \\
\text { front of the class and } \\
\text { set an example for } \\
\text { other students. }\end{array}$ \\
\hline $\begin{array}{c}\text { Students are allowed to disassemble the } \\
\text { teaching aids and try to understand the } \\
\text { various building components (C). }\end{array}$ & $\begin{array}{c}\text { Students pay attention } \\
\text { and try the teaching } \\
\text { aids. }\end{array}$ \\
\hline $\begin{array}{c}\text { Students are given feedback in the form of } \\
\text { spontaneous questions (C). }\end{array}$ & $\begin{array}{c}\text { Students try to answer } \\
\text { questions. }\end{array}$ \\
\hline
\end{tabular}

Table 7. Closing activities

\begin{tabular}{|c|c|}
\hline Teacher Activities & Student Activities \\
\hline $\begin{array}{l}\text { The teacher conveys the lesson that has } \\
\text { been discussed }(\mathrm{S}) \text {. }\end{array}$ & $\begin{array}{l}\text { Students listen and pay } \\
\text { attention. }\end{array}$ \\
\hline $\begin{array}{l}\text { The teacher gives the students questions } \\
\text { related to building components }(\mathrm{S}) \text {. }\end{array}$ & $\begin{array}{l}\text { Students take the test } \\
\text { given by the teacher. }\end{array}$ \\
\hline $\begin{array}{l}\text { Students and teachers evaluate learning } \\
\text { outcomes (S). }\end{array}$ & $\begin{array}{l}\text { Students take notes on } \\
\text { the assignments given } \\
\text { by the teacher. }\end{array}$ \\
\hline $\begin{array}{l}\text { The teacher conveys the follow-up to the } \\
\text { next lesson }(\mathrm{S}) \text {. }\end{array}$ & $\begin{array}{l}\text { Students listen and pay } \\
\text { attention. }\end{array}$ \\
\hline
\end{tabular}

The subsequent stage is observation. Observation activities in this research were carried out to observe all indicators of student activity during learning. Each student activity was recorded on the observation sheet. In this research, the writers collaborated with the team-teaching teachers. In this regard, the teachers acted as implementers (teaching), while the writers were observers.

After that, reflection was carried out. Reflection here is defined as an effort to examine what has happened and what has been produced or has not been completed in the 
previous step as consideration for taking the following actions. In this study, the results obtained during the action at the first meeting became a guideline for taking action at the next meeting. The deficiencies that occurred in the first meeting were corrected at the next meeting, and so on. With Cycle II, an overall picture would be obtained, and the answers to the problems raised would be known.

Based on the implementation results of the ARCS learning model with the help of teaching aids carried out in three cycles, it could be concluded that starting from the pre-cycle, Cycle I, Cycle II to Cycle III, there has been an increase in cognitive, affective, and psychomotor assessments. Student learning outcomes in Cycle III showed optimal results and had achieved the previously set results. The comparison of the action results between the pre-cycle, Cycle I, Cycle II, and Cycle III is described as follows:

In terms of completeness achievement of minimum learning outcomes, cognitive results in the pre-cycle, Cycle I, Cycle II, and Cycle III experienced a significant increase. Starting from the pre-cycle, student completeness was $24.3 \%$ to $41.9 \%$ in Cycle I. Since it has not reached the minimum completeness criteria indicator of 77 with $75 \%$, the students were treated in the next cycle. After treatment in Cycle II, there was an increase in cognitive aspects of $45.2 \%$ and continued to increase in Cycle III by $87.9 \%$.

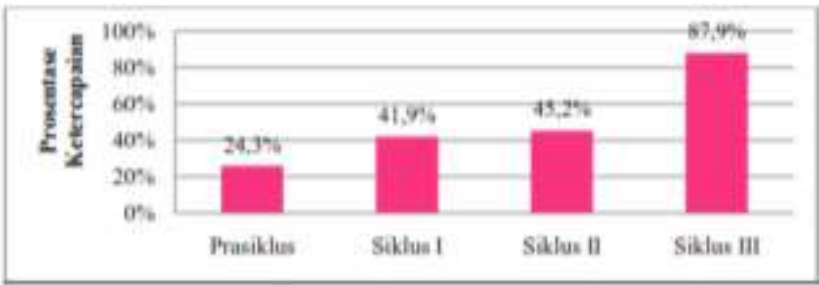

Fig. 1. Minimum score completeness improvement graph

Affective domain assessment in Cycle I, Cycle II, and Cycle III used five of eight student activity classifications taken from 177 kinds of student activities in the learning process by Paul B. Diedrich [2]. These five aspects encompassed visual, oral, mental, listening, and emotional activities. These five aspects represented the affective domain assessment. These aspects have also been adapted to classroom learning; thus, the points taken followed the budget estimate plan learning.

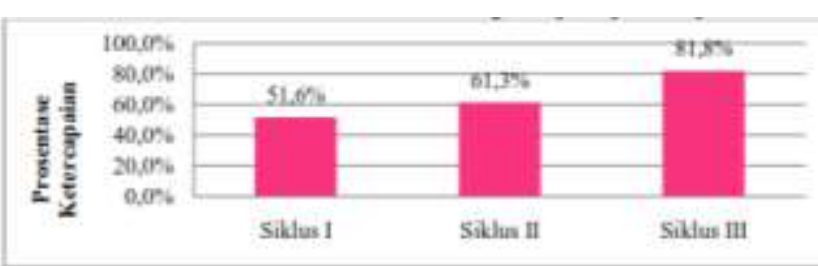

Fig. 2. Student improvement results in affective aspect

The psychomotor results in Cycle I, Cycle II, and Cycle III were based on three of eight student activity classifications taken from 177 kinds of student activities in the learning process by Paul B. Diedrich [3]. These three aspects included motor, writing, and drawing activities. In Cycle I, the result obtained was $32.3 \%$ completeness. In Cycle II, the result was $58.1 \%$, while in Cycle III, the completeness result was $87.8 \%$. It indicated that the psychomotor aspect experienced completeness from a predetermined limit of $75 \%$.

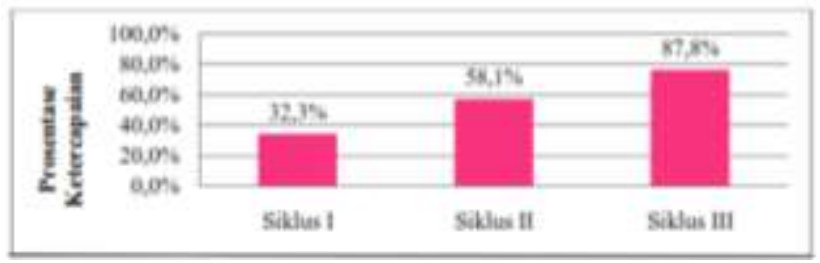

Fig. 3. Student improvement results in affective aspect

Moreover, student competency scores were obtained from comparing three aspects of cognitive, affective, and psychomotor assessment in Cycle I. It means that if a student got a minimum completeness score in one aspect but did not pass in another, the student was declared not to have passed.

Table 8. Student competency score in cycle I

\begin{tabular}{|l|l|l|}
\multicolumn{2}{|c|}{ Table 8. Student competency score in cycle I } \\
\hline Completeness Percentage & Complete & Not Complete \\
\hline Total students & 8 & 23 \\
\hline Completeness Percentage & $25.8 \%$ & $74.2 \%$ \\
\hline
\end{tabular}

From the results obtained, the completeness percentage in Cycle I was $25.8 \%$. It indicated that the average class had not passed the predetermined level of $75 \%$.

\begin{tabular}{|l|l|l|}
\hline & & \\
\hline & Table 9. Student competency score in cycle II \\
\hline Completeness Percentage & Complete & Not Complete \\
\hline Total students & 11 & 20 \\
\hline Completeness Percentage & $35.5 \%$ & $64.5 . \%$ \\
\hline
\end{tabular}

The results revealed that the completeness percentage in Cycle II was $35.5 \%$. It signified that the average class had not passed the predetermined level of $75 \%$.

Table 9. Student competency score in cycle II

\begin{tabular}{|l|l|l|}
\hline Completeness Percentage & Complete & Not Complete \\
\hline Total students & 19 & 8 \\
\hline Completeness Percentage & $75.8 \%$ & $24.2 \%$ \\
\hline
\end{tabular}

From the results obtained, the completeness percentage in Cycle III was $75.8 \%$. It demonstrated that the average class had already experienced completeness as previously determined, which was $75 \%$. After calculating the three assessment aspects, the competency score was obtained by 
comparing the three aspects. The competency score obtained in each cycle increased, starting from Cycle I of $25.8 \%$, Cycle II of $35.5 \%$, and Cycle III of $75.8 \%$ from the specified limit of $75 \%$. It showed that applying the ARCS method to SMKN 2 Sukoharjo students could improve their learning outcomes.

The study results have proven that the implementation of the ARCS-based learning model could enhance students' academic achievement, in this case, the learning outcomes. This success of improving learning outcomes could not be separated from the stimulus provided through a series of ARCS-based learning. It is because concentration in learning is an essential part of the ARCS learning model [4]. Besides, the model components that synergize will be able to grow other competencies, such as students' motivation in participating in learning activities, independent learning abilities, critical thinking skills, communication skills, and mastery of problem-solving through contextuality of the material that being taught [5], [6], [1]. The study results, showing an increase in each cycle, disclosed that in the learning process, it took time for teachers and students to adapt to a learning model. Therefore, teachers are expected to remain diligent and consistent in providing innovation by implementing interactive learning models under the 2013 curriculum provisions [7]; for example, innovation in learning models with a scientific approach and integrated with technology [8], [9], [10]. Thus, the learning process will be able to run optimally, which will then have implications for improving learning outcomes and mastering the determined competencies. Through this research, it was also grasped that a teacher must be able to follow technological developments and advances in learning management, proven by conventional and one-way learning methods that could cause delays in the process of achieving learning objectives.

\section{Conclusions and Recommendation}

Based on the classroom action research results conducted, it showed that using the ARCS learning model could improve student learning outcomes in the cognitive, affective, and psychomotor domains. It was proven by increased score results, and those have achieved the minimum completeness planned in the three domains from Cycle I to Cycle III. Because the ARCS learning model could maintain student motivation, it influenced the atmosphere to participate in classroom learning. Moreover, with the help of building component teaching aids, it could assist students to visualize the actual house building, helping them calculate budget needs in budget estimate subject. Therefore, it could be stated that the ARCS learning model and building component teaching aids could improve student learning outcomes at Vocational High School 2 Sukoharjo.

Based on the research carried out and the results obtained, the researchers could convey the study's limitations and provide some suggestions for other researchers to carry out further studies, with the ARCS model and building component teaching aids, it is hoped to help other learnings, support student learning outcomes, and lead vocational high school students to participate in various competitive activities related to building techniques, the building component teaching aids utilized can be further refined to increase students' interest and curiosity. The use of building component teaching aids can also be used for other learnings but is still related to building techniques, the teachers should actualize themselves with the latest learning models to better and create varied learning in the future, and other teachers who have not implemented learning using the ARCS model and building component teaching aids can apply the learning to increase the student's motivation and enthusiasm in participating in teaching and learning activities. However, it must also be adjusted to each school's ability.

Many researcher can compare this study with other studies that use building component teaching aids or ARCS model. Also, it can be useful for the world of education in Indonesia.

\section{References}

[1]. H. Rohmad, "Peran Kepala Sekolah Dalam Mengembangkan Eksistensi SMK," Media Manaj. Pendidik., vol. 2, no. 1, p. 167, Jun. 2019, doi: 10.30738/mmp.v2i1.3324.

[2]. R. E. Murtinugraha, "Evaluasi Pelaksanaan Kurikulum 2013 pada SMK Negeri Program Keahlian Teknik Bangunan di Jakarta," J. PenSil, vol. 6, no. 1, pp. 21-28, Feb. 2017, doi: 10.21009/jpensil.v6i1.7250.

[3]. N. Wahzudik, "Kendala dan Rekomendasi Perbaikan Pengembangan Kurikulum di Sekolah Menengah Kejuruan," Indones. J. Curric. Educ. Technol. Stud., vol. 6, no. 2, pp. 87-97, Nov. 2018, doi: 10.15294/ijcets.v6i2.26712.

[4]. S. Suhardjono, "kecenderungan gaya belajar mahasiswa pendidikan teknik bangunan," Param. J. Pendidik. Univ. Negeri Jakarta, vol. 27, no. II, p. 136, Dec. 2015, doi: 10.21009/parameter.272.05.

[5]. B. Kartowagiran, H. Retnawati, Sutopo, and F. Musyadad, "Evaluation of the implementation of curriculum 2013 vocational," Int. Conf. Educ. Res. Innov. (ICERI 2017), 2017.

[6]. C. Candra and H. Retnawati, "A Meta-Analysis of Constructivism Learning Implementation towards the Learning Outcomes on Civic Education Lesson," Int. J. Instr., vol. 13, no. 2, pp. 835-846, Apr. 2020, doi: 10.29333/iji.2020.13256a.

[7]. H. Retnawati, S. Hadi, and A. C. Nugraha, "Vocational High School Teachers' Difficulties in Implementing the Assessment in Curriculum 2013 in Yogyakarta Province of Indonesia," Int. J. Instr., vol. 9, no. 1, pp. 33-48, Jan. 2016, doi: 10.12973/iji.2016.914a. 
[8]. G. F. Friskawati and A. Sobarna, "Faktor Internal Pencapaian Hasil Belajar Pendidikan Jasmani pada Siswa SMK," J. Penelit. Pendidik., vol. 18, no. 3, pp. 327-335, Jan. 2019, doi: 10.17509/jpp.v1813.15004.

[9]. M. Marwa, M. Munirah, A. D. Angriani, S. Suharti, A. Sriyanti, and R. Rosdiana, "peran guru dalam meningkatkan minat belajar peserta didik kelas iv pada masa pandemi covid-19," AULADUNA J. Pendidik. Dasar Islam, vol. 7, no. 2, p. 215, Dec. 2020,

doi:

10.24252/10.24252/auladuna.v7i2a10.2020.

[10]. A. B. Barron, E. A. Hebets, T. A. Cleland, C. L. Fitzpatrick, M. E. Hauber, and J. R. Stevens, "Embracing multiple definitions of learning," Trends Neurosci., vol. 38, no. 7, pp. 405-407, Jul. 2015, doi: 10.1016/j.tins.2015.04.008.

[11]. R. W. Pratama, S. Sudiyanto, and R. Riyadi, "The Development Of Attention, Relevance, Confidence, And Satisfaction (ARCS) Model Based on Active Learning to Improve Students'learning Motivation," Al-Jabar J. Pendidik. Mat., vol. 10, no. 1, pp. 5966, Jun. 2019, doi: 10.24042/ajpm.v10i1.4044.

[12]. J. M. Keller, "Motivation, Learning, and Technology: Applying the ARCS-V Motivation Model," Particip. Educ. Res., vol. 3, no. 2, pp. 1-15, Aug. 2016, doi: 10.17275/per.16.06.3.2.

[13]. A. M. Afjar, Musri, and M. Syukri, "Attention, relevance, confidence, satisfaction (ARCS) model on students' motivation and learning outcomes in learning physics," J. Phys. Conf. Ser., vol. 1460, p. 012119, Feb. 2020, doi: 10.1088/17426596/1460/1/012119.

[14]. W. L. Lumbantobing and Haryanto, "Effect of ARCS Model on Learning Independence of 21st Elementary School," J. Phys. Conf. Ser., vol. 1233, p. 012105 , Jun. 2019, doi: 10.1088/17426596/1233/1/012105.

[15]. A. S. Sadiman, Media Pendidikan: Pengertian, Pengembangan dan Pemanfaatannya. Jakarta: PT Raja Grafindo Persada, 2014.

[16]. N. P. Dinayusadewi, G. Ngurah, and S. Agustika, "Development Of Augmented Reality Application As A Mathematics Learning Media In Elementary School Geometry Materials," J. Educ. Technol., vol. 4, no. 2, pp. 204-210, 2020.

[17]. M. Maimunah, "metode penggunaan media pembelajaran," Al-Afkar J. Keislam. Perad., vol. 5, no. 1, Dec. 2016, doi: 10.28944/afkar.v5i1.107.

[18]. D. Saputra, R. Ishak, and S. Setiaji, "Perancangan Website E-Commerce Sebagai Media Penjualan Miniatur Bus," Syntax Lit. ; J. Ilm. Indones., vol. 4, no. 12 , p. 87 , Dec. 2019 , doi: 10.36418/syntaxliterate.v4i12.831.

[19]. S. WONDO SAPUTRO, "pengembangan media animasi berbasis powerpoint menggunakan model pembelajaran langsung pada kompetensi dasar menjelaskan macam-macam sambungan kayu di smk negeri 3 jombang," J. Kaji. Pendidik. Tek. Bangunan, 2016.
[20]. D. Dimyati and M. Mudjiono, Belajar dan Pembelajaran. Bandung: PT Rineka Cipta, 2012.

[21]. N. Sudjana, Penilaian Hasil Proses Belajar Mengajar. Bandung: PT Remaja Rosdakarya, 2012.

[22]. A. Wahyu, N. P. U. P. G. P. S. A. P. Karang, M. Yudana, and N. Natajaya, "kerja guru terhadap kinerja guru smp negeri 1 bangli," e-Journal Progr. Pascasarj. Univ. Pendidik. Ganesha, vol. 4, no. 2, 2013.

[23]. Y. Puspitasari and S. Nurhayati, "Pengaruh Model Pembelajaran Discovery Learning Terhadap Hasil Belajar Siswa," J. Pendidik. Dan Kewirausahaan, vol. 7, no. 1, pp. 93-108, 2019, doi: 10.47668/pkwu.v7i1.20.

[24]. S. Suherman, A. M. Zaman, and F. Farida, "Fostering of Mathematical Critical Thinking Ability Using ARCS Model and Students' Motivation," JTAM (Jurnal Teor. dan Apl. Mat., vol. 5, no. 1, p. 134, Apr. 2021, doi: 10.31764/jtam.v5i1.3798.

[25]. P. Piriyasurawong, "Active learning using ARCS motivation on social cloud model to enhance communication skills in foreign language," TEM J., vol. 8, no. 1, pp. 290-297, 2019, doi: 10.18421/TEM81-40.

[26]. M. Çevikbaş and Z. Argün, "An Innovative Learning Model in Digital Age: Flipped Classroom," J. Educ. Train. Stud., vol. 5, no. 11, p. 189, Oct. 2017, doi: 10.11114/jets.v5i11.2322.

[27]. I. K. V. Astrawan, I. N. Martha, and I. W. Artika, "application of saintific-innovative learning models in indonesian teachers," J. Penelit. dan Pengemb. Sains dan Hum., vol. 3, no. 1, p. 51, Apr. 2019, doi: 10.23887/jppsh.v3i1.17364.

[28]. V. T. Suharto, A. M. Waraulia, and T. Hermayani, "The implementation of innovative learning models and based hots scientific approach on lesson plan of Indonesian language at schools," J. Phys. Conf. Ser., vol. 1464, p. 012023, Feb. 2020, doi: 10.1088/1742$6596 / 1464 / 1 / 012023$.

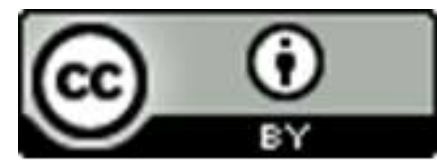

